Miscellanea Anthropologica et Sociologica 2019, 20(1): 15-35

Irene Breuer ${ }^{1}$

\title{
The Ego as Moral Person. Husserl's Concept of Personhood in the Context of his Later Ethics
}

Husserl's philosophy has ethical roots. In the well-known Crisis text, he speaks of the task of philosophers as "functionaries of mankind" (Crisis: 17). "To be human is essentially to be a human being in a socially and generatively united civilisation" (Crisis: 15). The philosopher bears a responsibility for "the true being of mankind" (Crisis:17) for it is through philosophy that mankind's being towards a telos can come to realisation. This task, to which "we are called" (Crisis: 17) can only be accomplished on the grounds of the human person as a moral person. In the following I would thus like to show that Husserl's statements are only comprehensible from out of the ethical-moral reflections underlying his concept of personhood in the context of his later ethical thought. An analysis of Husserl's concept of personhood can shed light on the task of philosophy and make comprehensible not only his phenomenological ethics but also his phenomenological anthropology.

Key words: Personalistic ethics, categorical imperative, absolute ought, person, value theory, Husserl

\section{Husserl's Concept of Personhood. General Remarks}

In Ideas II Husserl develops an ontology of the person. He begins by establishing different kinds of realities. Conceiving of a layered model, he first distinguishes between nature in the rather strict sense, that is, "material nature", and nature in a broader sense, i.e. "things which have a soul" or those "living, animal natures" which are the objects of physics. Husserl emphasises that what is at stake here is not an empirical reflection on nature, but an a priori investigation, which is carried out in a transcendental phenomenological way. In Husserl's words: "It is

1 Bergische Universität Wuppertal, Wuppertal (Germany); ibreuer@hotmail.com. 
clear that, in this sense, 'nature' is a sphere of 'mere things', a sphere of objectivities which distinguishes itself by means of a demarcation traced out a priori in the essence of constituting consciousness from all other spheres of objects that may be treated theoretically" (Ideas II: 27). To this end, he contrasts "the sphere of things experienceable by us" and the realm of "natural objects", and gains access to the former by performing "a sort of disengaging", i.e. an epoché. An epoché is necessary, because in scientific thinking, reality or substantiality and causality "belong inseparably together", i.e. "real properties are eo ipso causal ones" (Ideas II: 48), while phenomenology considers these material things only insofar as they correlate with things as given in themselves. He thus makes clear that we grasp these natural objectivities in the "natural scientific attitude", which is achieved only after we have performed a reduction on our everyday emotional intentions and on the apperceptions that have their origins in these intentions, for instance those of value. This is because in ordinary life we are guided to such an extent by our epistemological interests and our evaluative apperceptions that we perceive all things as endowed with certain value-based characteristics. In the theoretical attitude, by contrast, we grasp the experienced thing in its "materiality" and in "relation to 'circumstances"' (Ideas II: 44), i.e. in its 'relational reality', as we may call it. Through this shift in attitude we are able to grasp "the real" of the phenomenal thing itself (Ideas II: 46). It is thus obvious that the regional ontology of nature belongs to the realm of transcendental phenomenology, which operates on a priori grounds.

As to the second kind of reality, i.e. ensouled nature, Husserl introduces here a new concept of the Ego: The "I as human being", which is interwoven with other unities, i.e. the pure transcendental Ego and the empirical Ego - the unity of living body and soul. The "I as human being" is the Ego which is able to ascribe to itself not only its living experiences but its cognitions, its character traits and its own living body as well. Husserl's later reflections specify this conception of the "I as human being" and introduce the concept of the "personal Ego", which cannot be neither without the "subjective possessions" (Ideas II: 134) of its psychic life, i.e. its "original and acquired character traits, capacities, dispositions, among others." nor without its psychic lived experiences (Ideas II: 110f.). This personal Ego "has its spiritual individuality, its intellectual and practical abilities and skills, its character, its sensibility" (Ideas II: 147) and "a spiritual individuality", i.e. a "character, its sense-mode [Sinnesart]" (Hua XIV: 23). Thus, the apprehension in which a human being is given "as a person" "seems to contain a surplus" (Ideas II: 147) if compared to the apprehension of a human as unity of living body and soul, a surplus which for Husserl encompasses the possession not only of personal characteristics but of the world, insofar as persons live in a world on which they find themselves dependent (Ideas II: 47). This world concerns the person insofar as 
it engages itself not only in "experiencing" the "universal life" (Hua XIV: 46), but also in the activities of other "communities of persons", like social and religious institutions and more generally in law, morals, the state, etc. (Ideas II: 141). The participation of individual persons pertaining to this "surrounding world of spirit" in these institutions and in their dependence on them is defined as "monadic life" (Hua XIV: 46). The I-human being therein in his commerce with things and others is "a being who maintains (...) his individuality throughout." The concepts of "human being" and "I" are thus defined according to two different modes of apprehension and experience: the "psychological" one and the "human-scientific (personal)" one. On the one hand, the human being as "spiritually real" and the Ego as "personal Ego" are objects of "human-scientific (personal) apprehension", on the other, the human being "in the sense of nature" is an object of "naturalscientific anthropology" while the "spiritual" Ego is an object of "psychological apprehension" (Ideas II: 150).

At this point, we are confronted with a radical break between the naturalistic/ scientific approach on the one hand and the personal/ psychological attitude on the other, which in my view can be overcome in two steps: first, through Husserl's revision of his conception of the individual human essence and second, through the enlargement of this sphere to its universal-ethical dimension or, in Husserl's terms, to the concept of a "transcendental person" (Hua XXXIV: 200). In fact, Husserl's ground-breaking revision of the concept of "essence" - an "open" essence which can assume new properties according to varying circumstances - allows us to understand the modifications of the essence as resulting from the work of culture and science. The personal I is therefore bound to science and natural things through its cultural achievements. This individual personal I taken in its universal dimension, i.e. the "transcendental person", represents the highest level of Husserl's ethical considerations (Luft: 2012: 37). It is a person whose practical reality is underpinned by the work of science. I will take up these considerations at the end of the paper.

\section{The Pure Transcendental I as Personal I}

This twofold meaning of the "I as human being" can be enlarged to a third meaning provided that we take into consideration the reinterpretation of the pure transcendental I. In fact, the conception of the I as human being seems to have led Husserl to a revision of the I as an empty I-pole contained in Ideas I. The "the in-depth-thinking on the pure I" goes hand in hand with Husserl's investigations into habitualities and intersubjectivity and leads to the concretion of his conception of the monad (Marbach 1974: 305). And in a supplementary 
note to Ideas II, Husserl comes to the realisation that "the doctrine of the pure Ego - before all else as pole - must be [revised?]" (Ideas II: 324). He now claims that the pure I is not isolated from its context, but is given as a pole of "affects and actions" (Ideas II: 324). In Husserl's words, this inner structure, that is, "this pure I is also included in the personal I, each egoical act of the personal I is also an act of the pure I" (Ms. A VI 21, p. 21a and b as quoted in Marbach 1974: 315). The individuality of the personal I seems thus to have 'streamed into' the pure I: "This pure I as pole is nothing without its acts, without its stream of experience, without the living life that streams also into it" (Ms. E III 2, p. 5a as quoted in Marbach 1974: 304). Nevertheless, we should distinguish between the pure I and the I as person. Although the pure I neither originates nor decays, it is no common structure but a singular "I myself", an active subject, which perceives itself, has memories and phantasies. The I as "pure I" is self-conscious and unchanging in itself, while as "personal I", it is changing in its practices, in its activities and passivities (Marbach 1974: 313-316). Moreover, in self-perception, which is the pure I's self-reflection, the I identifies itself as the subject of each cogito and as the identical subject of its manifold actions and passions. Correlatively, the pure I conceives itself as subject of its "manifold possessions", i.e. that which is immanently or transcendentally pregiven (Ideas II: 260). Thus, the pure I cannot be conceived without its possessions affecting it. Moreover, it is "given in absolute selfhood" (Ideas II: 119), that is as a "centre of an identity" (Ideas II: $324)$; it remains unchanged as long as it "remains of the same conviction", i.e. although the Ego remains self-identical as pole, it changes along with its varying convictions. With reference to Paul Ricœur we may distinguish between the Ego's sameness "as synonymous with idem-identity" and the Ego's mutability as "selfhood understood as ipse-identity" (Ricœur 2012: 3). The Ego is thus selfsame although becoming other. Consequently, the pure I possesses a core of selfhood insofar as it is able to grasp its comportment and its motivations. This core of selfhood is itself unreflected insofar as it is the intentional object of the pure I. By way of self-reflection the I "know(s) about (its) unreflected Ego-life" (Ideas II: 260). Thus, the reflective I presupposes a pre-reflective self individualised by its actions and passions. The unreflected selfhood unfolds thus in factual life as factual existence and is retroactively experienced as an I endowed with personality by way of the pure I's reflection: the pure I comes across itself as an already existent and singular I. This means that the pre-reflective self as preexistent is retroactively uncovered as such by the pure, transcendental I. 


\section{The Third Level: \\ The "Personal Reality" and the Constitution of an Ethos}

Summarising the above, we can conclude that human beings as persons have the pure I's functional capacity in common; but they nonetheless vary according to the "how", i.e. the specific character and qualitative content of this self-perception. The person as such is the subject of active intentionality but as self-reflected it uncovers its pure I, which in its turn uncovers in self-reflection a pre-reflective affective I as a passive ground. Both selfhoods, the pure I with its core of identity and the underlying affective I, are the conditions of the possibility for the constitution of a personal being with unique characteristics. To be a person means not only to be the subject of the Ego-acts i.e. of active intentionality, but also to be subject of affections and habitualities i.e. of passive intentionality.

Let us now consider the third level of reality: the "personal 'reality" (Ideas II: $262 \mathrm{fn} .1$ ). What is needed to reach this level is an "Objectivation of a higher level superposed on that of the other stratums of apprehension in such a way that what is constituted is the unity of an object, one which in turn (...) involves Objective strata of lower and higher levels, distinguishable only after the fact" (Ideas II: 256). Thus, we grasp an "objective spirit" (Ideas II: 256), a human being, a "personal subject" in relation to the acts which it itself performs through motivation, and with "personal features or properties of character". Husserl distinguishes here between the "pure-Ego-reflection", that is, the reflection on the pure Ego that every Ego performs, and the "reflective thematic experience" i.e. the reflection on the empirical Ego that the personal Ego performs to uncover the "experiential nexuses" in which it shows itself (Ideas II: 261). This "personal Ego is the human Ego." But repeated reflection on myself does not suffice to let an "an experiential apperception of the Ego" originate, as personal Egos exist in a community of other human beings (Ideas II: 262). Thus, the personal Ego experiences not only its own comportment but also the comportment of others within the shared surrounding world. Insofar as the personal I experiences itself in its own behaviour and at the same time apperceives itself in a "human nexus", it comes to know itself as a "personal 'reality"' (Ideas II: $262 \mathrm{fn}$. 1). This means that the personal I has to perform an "inductive apperception" in order to be able to grasp itself as personal reality; that is to say, the ability to grasp itself as a real person requires being part of a community of other human beings that are Is. Thus, I am a person only insofar as I am a member of a community: to be a person is to be a social being.

The constitution of personal agreement with the Other presupposes an actual "being-for-each-other". In such a situation, the Self addresses the Other and reaches a primary understanding of the other's bodily perceiving and actions, i.e. its "bodily performances [leibliche Bekundungen]". But it is only through 
communication that a social agreement may originate, i.e. the sphere of the social (Hua XV: 479). The "speech bond" is for Husserl the "primary form of the communicative agreement" or sociality. Through this agreement there arises a "personality of a higher level" (Hua XV: 472) grounded on common habitualitites, i.e. shared customs, an êthos in the Aristotelian sense. The constitution of an êthos presupposes a practical intention which impels us to action or, in Husserl's words, an "intentionality of drives" (Hua XV: 594). This is because we are originally conjoined in a community of drives in the manner of an "intentional intermingling" (Hua XV: 366). Husserl understands this sphere as "radically pre-egoical":, it belongs to the lower strata of the stream devoid of Ego, i.e. to the sphere of the I but before the I is constituted as Self. Thus it belongs to the sphere of the "passivity devoid of Ego [ichlosen Passivität]" (Hua XV: 595). This insight allows Husserl to postulate a mutual constitution of the I and the world, insofar the constitution of the world on the one hand and of persons on the other can only be carried out by an intersubjective community and a transcendental intersubjective constitution of existing bodies respectively (Hua XV: 466).

This "pre-egoical" sphere in which I am not yet split from the Others, i.e. in which I am not yet individualised, is essentially different from the above mentioned pre-reflexive Self that possesses its own individuality. In fact, the personal I experiences itself as already existing, insofar as "the I does not originally arise out of experience (...) but out of life (it is what it is not for the Ego, but it is itself the Ego)" (Ideas II: 264). "I am the subject of my life", such that the I is primarily and originally a subject that constitutes objects to meet its primal needs, it "develops by living", it is "simply there" in its self-givenness and in its actions and passions. This 'simple being-there' is therefore the originary way a person is given. Only at a second stage does the I experience itself "in the sense of an associative apperception" (Ideas II: 264). This implies that the reflection which starts from the personal I uncovers the pre-reflective Self as a pre-given factual existent entity. Insofar as self-reflection has an "essential constitutive function" (Ideas II: 263), it can be understood as a retroactive constitution of the I.

In Ideas II, Husserl develops a stratified model of the I based on these insights by establishing different levels of apperceptions which presuppose the facultative possibility of an active intentionality. The lowest strata belongs to the pure I, the object of "pure-Ego-reflection" performed by the empirical I; the next strata belongs to the "empirical I" as an intentional object of "reflective thematic experience" carried out by the personal I insofar as it experiences itself; finally the last strata belongs to the personal I, which shows itself in relation to both the acts it carries out and in its personal character (Ideas II: 261). It is important to note that the personal I is the only I capable of consciously relating to others and to its surroundings, such that it opens itself up not only to the world, but to its own history. 
Through self-reflection as self-perceiving, it discovers aspects of its self formerly unknown to him, i.e. its "unreflected consciousness" (Ideas II: 255) and it comes to know itself as the I of its manifold actions and passions, which may vary in time according to circumstances. Self-reflection is therefore a unified process of both self-knowledge and individuation. The Self grasps itself in its selfhood insofar as it recognises the history of its transformations as its own while in a parallel fashion it grasps its ipseity insofar as it remains the same throughout its changes. To be a person is therefore to be a being which undergoes a changing life-history. The I as person is thus grasped in its diachronic singularity.

\section{The Person as the Subject of Acts of Reason and as a Free Ego}

Husserl conceives the personal I as a person in a specific and strong sense as "the subject of acts which are to be judged from the standpoint of reason, the subject that is 'self-responsible', the subject that is free" (Ideas II: 269). It is a matter of a demand not only of self-responsibility, but also of an active positioning and active thinking of the I, an Ego that takes decisions and positions for itself and does so "in the mode of reason" (Ideas II: 282), i.e. it "takes decisions based on 'grounds" (Hua XIV: 20f). The personal I is therefore a "person as the subject of acts of reason, whose motivations and motivating powers come to givenness in our own original lived experience as well as in the lived experience, available to us in empathy, of others" (Ideas II: 282). What is here displayed is its individuality, i.e. its "individual idiosyncrasy" which must be distinguished from the "individuation of uniqueness". "Individuation" relates to the general "I 'form' in its generality" and concerns each monad in its individualisation; individuation means thus numerical unity. By "individuality", by contrast, Husserl means the qualitative unity concerning the "qualitative idiosyncrasy" i.e. the freedom of the I to take decisions. There is an a priori manifold of possible acts or positions, but each act is "necessary out of pure possibility", i.e. it is "a priori (necessary) in a new special sense" (Hua XIV: 22). Husserl defines this a priori necessity in a new sense as an "individual necessity" (Hua XIV: 24). It concerns the essence of the individual being: if the I is "an identical I", that is, if the essence of a person is unchangeable - in Husserl's words if "I hold to myself as the I, that I am" - then "only one reasonably possible as the case may be" for each I, such that the "real decision is only one reasonably possible" (Hua XIV: 22f.). The I can think of manifold possibilities, but it is able to realize "intuitively" whether the possibility under consideration is compatible or incompatible with its own essence. An incompatible possibility for the I implies that the I is fantasised as an other I. Husserl still conceives of essence 
in an Aristotelian sense: there are certain possibilities potentially available the unchanging essence; possibilities which are a priori necessary but vary according to each individual. This is a conception that he later calls into question.

I am thus responsible for my theoretical convictions and not only for my acts, such that the person has, in addition to its qualitative idiosyncrasy or its "aesthetic character", a "moral" character (Ideas II: 284). The question of whether every person can comply with this requirement is left open. But it is clear that a human being "has its character, its person[ality], is a unity, constituted in the course of its life, as a subject of position-taking, i.e., a unity of multifarious motivations based upon multifarious presuppositions" (Ideas II: 286f.). But, as Husserl adds, "[w] hat is most proper to the person resides in the Ego as substrate of decisions and not in the Ego of mere faculties". That means it does not reside in the "practical" possibilities of the "I can". Every I as a "subject of position-taking and of habitual convictions" has its "style". The personal subject is dependent on motivations and is as a "subject of actual and possible decisions" determined not only by its idiosyncrasies but also by "factual relations": the subject is thus a "unity of determinations" (Ideas II: 342f) and these determinations have both a practical and a moral character.

\section{Husserl's Personalistic Ethics}

Hence, Husserl's statements about the person as a subject of acts of reason are only comprehensible from his ethical-moral reflections. In order to show how these conceptions are related, Husserl's reflections will first be placed in the greater perspective of the development of his axiology and ethics. Taken only in its chief contours, the discussion will focus on the ontology of the ethical subject on which his later ethics are grounded. Husserl's pre-war axiology and ethics of the categorical imperative and of the highest good as developed in the Göttingen lectures, which were strongly influenced by Brentano, will be briefly reviewed. Husserl's pre-war ethics comprises his lecture courses on axiology and ethics from 1902, 1908/09, 1911 and 1914, which lectures where mostly published in Hua XXVIII. His post-war ethics are located in manuscripts from the first half of the 1920s. Three lectures on Fichte's ideal of humanity can be found at the beginning of this period. These were mainly given in the winter of 1917-1928 and have been published in Hua XXV, p. 267-293. There is also the Freiburg lecture course from 1919-1920, entitled "Introduction to Philosophy", which was published for the most part in Hua Mat. IX, in Hua XXXV and in Hua XLII. Finally, in 1922/23 Husserl wrote various articles on "renewal" for the Japanese journal The Kaizo. These were published in Hua XXV. This overview (cf. Melle: 1991, 115f.), which is not intended to be complete, gives an insight into the principal phases of Husserl's 
ethical reflections. It will allow us to point out the features of an ontology of the ethical person that will enable us to solve the problem posed in Ideas II, namely, the break in the unity of ontological reality.

\subsection{The Ethics of the Categorical Imperative}

Husserl's early ethics is characterised by a search for analogues to the forms and laws of the intellect and its acts. He develops the idea of "parallel or analogous forms of rationality" (Melle 2002: 239), i.e. forms of emotional and volitional rationality whose objectivity and truth is analogous to those of the act of thinking. "A formal axiology and formal praxis as the sciences of the formal laws of the heart" are parallel to "formal logic as the science of formal laws of theoretical reason" (Melle 2007: 8; cf. Hua XXVIII: 49f.). One of the laws of formal axiology is of particular relevance, the law of absorption: "The better is the enemy of the good and the best absorbs everything else that can be appreciated as practically good in and for itself" (Hua XXVIII: 136, as quoted in Melle 2007: 9), from which the categorical imperative is deduced. This principle, which Husserl takes from Brentano, says: "Do the best that is attainable" (Hua XXVIII: 221). This is an imperative that is required to be made into a law of the subject's willing. This imperative is a noetic expression. "Objectively, the expression would be: the best attainable within the entire practical sphere is not merely the best comparatively speaking, but rather the sole practical good" (Hua XXVIII: 221 as quoted in Melle 1991: 120). The best attainable, although subjectively contingent, is objectively obliging: choice is guided by a will aiming at and grasping its own and whole realm of practical possibilities and must select the highest value therein (cf. Melle 2002: 236, Melle 1991: 120). The imperative thus allows for inclination and preference insofar as what we ought to choose is founded on value. Contrary to Kant's, Husserl's axiology is a "logic of the heart [Gemüt]" based on the relation of the heart to what appears as good and bad (Hart 1992: 299). The personal I decides to rule and shape its life according to the categorical imperative. Here a central thought of Husserl's ethics emerges, namely, the notion of a self-regulation of the whole of life based on the recognition of what is truly good, a notion that determines my own identity as an ethical subject.

But already in this period, Husserl questions the rational universalism and objectivism of his ethics, insofar as pure axiological laws do not provide the material value-content necessary to justify ethical choices (Hua XXVIII: 419-422; cf. Peucker 2008: 317; Hart 1992: 324f.; Melle 1998: xlvi-xlviii). First, any a priori value scale would contradict our ethical frame of decisions, insofar as the type of goods which are "absolutely obliging [absolut gesollten]" depends on the particular circumstances we are living through (Hua Mat IX; 144f). Second, rational willing 
and doing seems to be guided by the order of preference in practical realizable values that are established by evaluative acts that themselves institute this order of preference, such that this willing and doing would not realize any insight of its own (Melle 2007: 9). Finally, the categorical imperative can only be followed if values can be compared to one another (an objection raised to Husserl by the Munich Phenomenologist Moritz Geiger, cf. Hua XXVIII: 419f.; Hart 1992: 297-303, 324f.), something that exceeds formal axiology, insofar as only subjective processes enable us to experience something as of value. Although Husserl claims that feelings and emotions give us access to certain value-properties, these are nonobjectifying acts, a distinction that characterises the difference between reason and feeling consciousness (Peucker 2008: 317f.; cf. Peucker 2010: 60; Hua XXVIII: 260-269 and 332-344). The solution to this problem lies in the consideration of the subjective values of love that are the object of the subjective ethical will on the one hand and the acknowledgment of the Others' wills and values on the other.

\subsection{The Ethics of Love and the Absolute Ought}

In the later Freiburg lecture course of 1919/20, "Introduction to Philosophy" (cf. Hua Mat. IX, 1-287; Hua XXXV, 43-46; cf. Melle 2002: 237-241) and in writings on ethics of the same period (cf. Hua XLII, 265-527), which mark the transition to Husserl's later ethics, after stating the "evident, absolute validity" of the categorical imperative as an "unconditionally valid positive criterion of the ethically good and bad will" (Hua Mat. IX: 133), Husserl realises that the objective value has to be distinguished from the same value as an individual, subjective value of love (Hua Mat. IX, 146 Fn. 1, as quoted by Melle 2002: 238). This "problem of love", which is "one of the main problems of phenomenology" (Hua XLII: 524), leads him to question the validity of the categorical imperative. As Husserl explicitly admits: "I will have to renounce or set limits to the whole doctrine of Brentano's categorical imperative" (Hua Mat IX: 132 Fn. 1; cf. Hua XLII: 390). Insofar as love is "something specifically personal", the highest practical good may not coincide with the absolute ought (Hua Mat. IX, 132, Fn. 1). Personal values of love such as "individual values" (e.g. love for individual persons such as love for one's own child or for a friend, for personalities of a higher order such as one's own family or community or love of the neighbour) "make up the largest part of the values of an absolute ought" (Hua XLII: 337). In concrete situations, i.e. whenever individual values give rise to concrete duties (e.g. whenever washing the own child becomes a duty out of love or whenever playing a Mozart sonata is to be preferred over some pleasurable activity), (Hua XLII: 390), the formal imperative is concretised in an "individual categorical imperative of the moment [individuellen kategorischen Imperative der Stunde]”, (Hua XLII: 377; cf. Melle 2002: 244), which prescribes 
what is to be done as "absolute ought" (Hua XLII: 390 and 321). In case of conflict, absolute values of love have a priority over objective values: to go against the former would amount to a self-betrayal, a "betrayal of one's own essence" (Hua XLII: 377; cf. Melle 2002: 244). All these personal absolute values are equally absolute such that the law of absorption cannot be applied to values of personal love. In case of having to choose, there is only one option left: to sacrifice one value for the sake of another, which amounts to a sacrifice of oneself. (Hua XLII: 346 and 415; cf. Melle 2002: 244). Hence, if on the one hand the "absolute ought essentially concerns absolute values, persons and their personal and ideal values" (Hua XLII: 377) and if on the other, absolute values cannot be submitted to the law of absorption, then Brentano's categorical imperative cannot be applied to certain kind of values insofar as it is grounded on precisely that law of formal axiology (cf. Sowa, Vongehr 2014: cvi).

Brentano's formulation is insufficient "for the voice of conscience, of the absolute ought, can demand something from me that I would in no way recognise as the 'best' in a comparison of values" (Hua XLII: 390). Each of us has our own absolute ought "and what is to be chosen must answer not to what is the best, but to the question 'What ought I?'; (...) or 'Which is now necessary to me?' [Was soll ich? (...) Welches ist jetzt mein Notwendiges?]", (Hua XLII: 390). However insufficient, Brentano's formulation is still valid in the realm of objective values, namely to those to which a "neutral observer" bound by a generally valid willing and acting would actually endorse (Hua XLII: 351 ). These objective values arise out of the special characteristics of the object, which motivates a practical apperception of the subject. Insofar as subjective values are concerned, the direction of the intentional ray is inverse, because it is now from the subject that a "loving valuing" emanates towards this object (Hua XLII: 352). Should the imperative not be valid for a realm of subjective values, then the ethical rationalism implied in it would not seem to apply either. Husserl explicitly admits a moment of irrationality: "Among the persons of my environment, my child is the 'closest' to me, and therein is contained an irrationality of the absolute ought" (Hua XLII: 384 as quoted by Melle: 1991: 134). The rationality of the absolute ought seems to house a 'core' of irrationality, "irrational' existences and values, the irrational truths (truths of being)", (Hua XLII: 350), which are connected with the 'irrational' values of love, namely those values that being absolute, exceed any scale of values (Hua XLII: 352). However, this is not Husserl's final word on the irrationality of rationality. We will return to this later on.

In this context it is important to note that ethical duties differ from moral ones: the example of the call to a duty or vocation shows that an ethical obligation may arise not only out of the values of personal love that address what is considered good in itself, be it for my own or in others' benefit (Hua XLII: 278), but from 
other value-realms such as the love for a certain profession. Whenever this calling, initially "instinctively" aimed at, becomes a conscious, life-determining aim of the will (Hua XLII: 359), endorsing the norm that requires us to live "in ethical seriousness", i.e. to live "in the seriousness of the decision for a true and authentic Dasein", then such a calling is to be regarded as a model for the ethical life generally (Hua XLII: 455). Husserl points here to a central theme of his late ethics: the absolute ought grounded in the personal love and calling of the subject which, together with the striving for the autonomy of reason, make up the individual essence of a person. In Husserl's words: "The realm of values [is] personally rooted insofar as realm of general norms. It belongs to the 'essence' of each personal individuality to have a realm of personal decisions, personal love, personal ought (...), types, classes of personal values and corresponding general and a priori norms" (Hua XLII: 344). Husserl does not renounce his former axiological ethics, he rather endows it with a grounding affective structure that provides ethics with a material content, namely, the subjective values of love, such that not only the will and the call for a particular vocation but the whole life of a person now become linked to the absolute ought of love.

\subsection{The Love of Eternal Values and Fichte's Influence}

It is in connection with Fichtean themes that the categorical imperative fuses in certain respects with the absolute ought, thus giving rise to the idea of an ideal position-taking that brings blessedness and allows for a material-teleological formulation of the "necessary (...) love for eternal values", namely a "positive" and "highest blessedness" (Hua XXV, 287). Striving for a life that is self-determined and self-responsible amounts to a blessed life: "A blessed total life as such would be a unified life in which all its intentions and all its striving would run into the form of filled intentions" (Hua XXXV: 44). Much in Fichtean terms, Husserl defines the "universal, philosophical doctrine of reason" as "the science of the reasonable or truly good life as such, or of the blessed life" (Hua XXXV: 45), whose principal task is to contribute to the fulfilment of a "blessed life in common" (Hua XXXV: 44) of the individual and the community as well. We find here the second step of the solution for the lack of its own content in the personal will: only within life in a community and with the acknowledgment of Other's values can individual willing and doing realize its own insights. The subject can master its own life, it can overcome doubt, negation, lack of values and certainties only if it both leads a life under the guidance of reliable knowledge and conscience, i.e. a life that is wholly self-justifying and strives for rational autonomy within an encompassing community. Blessedness characterises an intentional life that is not only subjectively satisfying, but is "a life of firm and positive knowledge and conscience" 
that withstands reflective critique and is justifiable in its totality (Hua XXXV: 45). Hence, the recognition not only of what is simply good but of the good as such needs to be expressed in an activity that acknowledges the Other and what he/she considers the best. This performance can be understood as a "moral act" which is "caught up in the categoriality" and thus constitutes the distinctive moment of a moral category (Sokolowski 2017: 60-63). ${ }^{2}$ The absolute ought, as that which is required for each individual's self-realization and true self-preservation, is an instance of the general features of the categorical imperative that determines the best on the basis of a correctly motivated will (Hua XXXV: 45; Hart 1992: 318).

The content of the absolute ought of love developed in his three post-war lectures on "Fichte's Ideal of Humanity" is determined by the way the divine entelechy effected by the world-life's idea "is profiled through an individual life in a concrete situation" (Hart 1992: 324; cf. Hua XXV: 267-293). The revelation of the absolute ought must be made into a law of my willing and it is proper to and distinctive of each person according to its unique situation. Although the evidence will always be inadequate, there is an absoluteness in the form of determination of both the absolute ought as the truth of the person and the good to be chosen whenever it is loved for the sake of itself, namely, provided it is not a mere means (Hart 2002: 325f.; Hua XXV: 288). Only a true ethical will transforms life into an ethical life. A particular form of such a general will is the choice of vocation that makes up my true self, such that the categorical imperative demands the ethical subject to devote himself to the pursuit of a particular class of values (cf. Melle 2002: 239). The position-taking in which a person orders all his/ her life under the guidance of this true self, i.e. the primary ethical task, is called "the ethical truth of the person", a truth that has both a formal-logical as well as a pre-logical, "situational" [Situationswahrheit] character (Hua VIII: 297). It is a truth which concerns the particular subject of the will and its individual life, as such it is called "the truth of the will [Willenswahrheit]" (Hua XXXV: 252). Hence, the ideal of the true self, namely the absolute ought, is a leading of a life in analogy to a career towards which all decisions and projects are ordered and unified (Hart 1995: 151). My choices and my position-takings therefore constitute my personal identity: my person is constituted by such and such position-takings. But it is clear that my acts disclosing my truly being me, those characteristics that define my essence, are inseparably linked with those of Others (cf. Hart 1992: 328; Hua XXVIII: 176), such that, as we have seen, individual ethics opens up to a social, communitarian ethics. True love of self is inseparable from true love of the neighbour [Nächstenliebe],

2 Although Husserl ties "the ethical" not to this practical acknowledgment of the Other but to a good, true and ideal life, he states that we are originarily intermingled with Others, such that our search for our true self is inseparable from the search by Others and the love of my self is interwoven with the love for Others (Hart 1992: 308). 
(cf. Hua XXXVII: 10-12; Hua XIV: 165-84, 192-204). The spiritual life of both, the individual person or a social personality of a higher order, i.e. a community, is a personal life, insofar as only a person can build up an ethical will in response to its capacity to conceive the wholeness and unity of his life. Husserl's later ethics is grounded on such an "ontology of the spirit or of personal life", as developed in the Kaizo articles of the early 1920s and in the above-mentioned manuscripts with respect to the values of love.

\subsection{The Ontology of the Ethical Subject}

The foundation of Husserl's later ethics is an ontology of the person, but not the person as such (as was developed in Ideas II) but as an ethical subject. Persons are characterised by three essential traits. First, they are responsible for their own being, that is, for their convictions and for their acts. A person, however, is not pure freedom, but is determined by passivity. On the one hand, passivity comprises primal instincts and drives, which affect the rational activity of the ego and on the other, it concerns the history and the factual determinations of its life as a whole (Melle 2012: 243f.). The sphere of the person thus has an entirely different ontology to that of natural things, as was stated at the beginning of this article. Husserl emphasises that personal life is determined by pre-egoical striving tendencies (Hua XXVII: 25), which express themselves in knowledge-intentions as a striving for clarity and fullness and which are articulated in actions of will that aim at obtaining what is desired (cf. Hua XXXVII: 248). These personal strivings aim at a state of fulfilled happiness, namely that of "eudaimonia" (cf. Hua XXVIII: 11; Hua XXXVII: 37 and 44; Hua XLII: 303 and 469) in the Aristotelian sense of the word (cf. Peucker: 2010: 62-65). An ethics whose task is to discover the aims of our strivings and the means to realise them can provide a practical orientation when it comes to selecting the "essence of practical goods", namely that which makes them true and authentic (Hua XXVIII: 37). Therefore, "ethics always wanted to be a theory and a practical discipline of the perfect human life and human being, a theory and practical discipline of the methods of self-shaping of the subject and its life to perfection or to happiness" (Hua XXXV: 46, as quoted in Peucker 2008: 321). However, such a state is not at all attainable for human beings, because our life is characterised by disappointments, errors, inhibitions of our strivings and what Husserl later calls the "core of 'primal contingency' [Kern von 'Urzufälligem']", (Hua XV: 386), of our factual life, namely, the irrational contingencies to which the subject is exposed in the course of its life. By this 'primal contingency', Husserl means the open possibilities of the "irrational or senseless [Unsinnigkeiten]" - destiny, death, illness and misery (Hua XLII: 398) and of the "senseless fortuitousness [unsinnige Zufällen]", insofar as "the being of absolute 
human beings" is a mere "contingency, contingency of their surroundings, upbringing, education, health and illness" (Hua XLII: 409 and 300). The world is "unpredictable; would it itself be predicable, it would be of no avail to the I, which has bumped into it by hazard and fate and which is dragged around by and in it" (Hua XLII: 286). Hence, the Ego is not only subject to pre-existing structures imposed upon it, but also to future contingencies over the course of its life. The I bumps into an already existing world - as Husserl claims: "I have not chosen my life" (Hua XLII: 409) - and is born amid a family and a certain community, in particular surroundings under particular historical circumstances, in a cultural tradition, in a determinate place in time and space and so forth, which were already constituted by others and which it has to retroactively endow with sense. We may thus conclude that phenomenology's realm is enlarged to encompass the problems concerning the irrationality, indeterminacy and contingency of factual life which the subject is powerlessly and frequently unwillingly subject to.

Such experiences motivate a critique that affects the sphere of our aims, i.e. the sphere of praxis and will. Although Husserl claims that virtuous acts conform to a kind of "second nature" of the person, this is not passively acquired in a process of habituation but it rather requires the Ego to be the "causa sui" of its own morality to the extent that it is "determined by itself as being thus", aiming at goals that are wanted and effected on grounds of a self-evaluation (Hua XXXVII: 163). Husserl stresses here the importance of a critical self-reflection or self-evaluation to the constitution of an ethical life insofar as this life presupposes a radical self-critique through which the personal I can arrive at a higher form of consciousness and thus reorganise its whole life. Husserl calls this process "renewal [Erneuerung]". In his "Essay on Renewal" from 1922-1924, Husserl defines ethics and ethical life by this concept of renewal: "Renewal of humans, of the individual human as well as the communalised humanity, is the chief theme of all ethics. The ethical life in its essence is one that stands consciously under the idea of renewal, a life guided and shaped willingly by the idea of renewal" (Hua XXVII: 20, as quoted in Melle 2007: 10). Self-consciousness, personal selfcontemplation, self-evaluation and self-determination are the essential traits of persons that distinguish them from the "passive-unfree" strivings (inclinations, affects) of other living beings (Hua XXVII, 23f.). Hence, the human as person oversees its life and aims at universal values. There are two types of human life or types of persons. The first one concerns a pre-ethical level comprising the choice of a career while the second one concerns life-history at a lower level, wherein the person commits itself to leading a life according to reason. At the third level, the human form of life attains its absolute sense, "a life-form of authentic humanity": the I has taken the resolution to shape itself into an "authentic and true human being", who not only leads and justifies its life according to reason, but 
whose theoretical, practical and axiological reason strives to reach the ideal of "absolute, personal perfection" (Hua XXVII: 29-35).

\subsection{The Ethics of Renewal}

This renewal aims at the "authentic" person, a person that can have or experience values. To experience them, it has to feel emotions: this process of valuing already starts at the apperception of emotions aroused by the feelings of pleasure and displeasure, which in turn constitute the sensation-material subjected to the valuing act (cf. Hua IV; Hua XI). The experiencing of values is required in order to hear the call for the "absolute ought" that consists in leading a purposeful and active life guided by "truth, reason and rightness" and in accordance with our subjective capacities, that is, the telos is the "best possible life" relative to each subject's nature, as Aristotle demands. The ethical postulate thus consists in wanting and having the will to lead the whole of our life under the guidance of reason (Hua XXVII: 32f.). But "reason" is not an absolute telos insofar as it is relative not only to the "best possible" capacity or conscience (Hua XXVII: 34), but also to the "material state of affairs" in which the person is already situated (Hua XXVIII: 40f.). Listening to this inner call is not listening to the abstract voice of reason but instead answering our "positive drives" in their search for "positive values" (Hua XXVII: 25) guided not only by reason but also by "pure love" (Hua XXVII: 28). Hence, embracing this quest is first of all an act of love, a love for the pursuit of rationality and a question of emotions.

The human being is motivated by love to search for these ideal values and this is an ideal that does not transcend it but arises "out of itself", out of "the living I", the "true" and "best I" (Hua XXVII: 35) that is able to justify its acts. Once this ideal I is found, the ethical demand is posed: the subject has to acknowledge that the ethical life-form is not only the relative best possible one, but also the only truly good one. In agreement with his ontology of the person and the ethics of the categorical imperative, Husserl defines ethics as "the science of the total life of action of a rational subjectivity, lived from the point of view of reason that regulates this whole life in a unified way" (Hua XXVII: 21). This ethical demand is defined as an "ethical imperative" whose demands are categorical. The subject can be valued as a "true subject" only insofar as it willingly submits to the categorical imperative: "Be a true subject, lead a life that you can wholly justify by insight, a life out of practical reason [Sei ein wahrer Mensch; führe ein Leben, das du durchgängig einsichtig rechtfertigen kannst, ein Leben aus praktischer Vernunft]", (Hua XXVII: 36). Husserl here advocates an unrestricted ethical rationalism which is grounded on a particular emotion: personal pure love. For Husserl, the moral person is a subject who is able to rationally justify its life, such that the 
ethical demand is a demand to assume a radical responsibility for one's own life. The quest for rational justification and self-responsibility does not arise out of a universal demand (Kant) but out of affective life, more precisely, the love for reason. Hence, the deepest being of the person and the root of its individuality is not to be found in reason and rational striving but in love. The personal I has a core of personal love from which it follows its vocation, its calling: "The I, which as such an innermost I and which is beckoned by this ownmost calling, this I, has individuality" (Ms. B I 21,55, as quoted in Melle 2007: 12) which expresses itself in the intensity and the direction of its love. Moreover, the demand for justification can only be complied with if the moral subject is a part of the community, of a "personality of a higher order" (Hua XXVII: 22). As mentioned above, to be a person means to be a moral person only insofar as embedded it is in a community: being a moral person is being a social being who engages in the love-driven pursue of rationality and self-determination. This ethical striving towards self-determination and self-justification which permeates our life as a whole can be understood as the foundation of Husserl's phenomenology insofar as it is determined by "a philosophical ethos": the ethical striving towards a true life wherein all acts can be ideally justified and accounted for (Peucker 2011:10) and which is ultimately driven by love.

\subsection{The Overcoming of Irrationality and Senselessness through Love and Faith}

For Husserl the irrationality of fate, contingency, death, illness, the possible failure of my own forces that prevent me from fulfilling my aims can only be surmounted if I remain "heroic", if I do not let these disappointments break me down (Hua XLII: 304). But, Husserl asks, what happens when "the attainable good continually dwindles" or "when I cannot hope that it will ever be different"? These questions lead Husserl to ask: "Can I live in a 'senseless' world?" (Hua XLII: 307f.). The answer lies in the loving care of a mother who doesn't give up even if confronted with the end of the world. She does her duty out of love, she perseveres, but she is far from being blessed. Blissfulness in the sense of eudaimonia is in tension with self-content and the categorical imperative (Hua XLII: 311). This conflict can only be resolved within a "community of love" (Hua XLII: 313) wherein each person not only acknowledges but takes over the values of Others as if they were its own. A subject as "functionary of an ethic community" does its best in relation to its surrounding world, thus attaining self-content and blessedness (Hua XLII: 316). However, neither the ideal of reason alone nor the idea of a community of love suffices to counterbalance the effects of the irrationality and senselessness of our lives: only a rational faith in a divine teleology or a divine arrangement of 
the world can reconcile us with rationality and sense: "I can be blessed, and I can only be such in all suffering, misfortune, and irrationality of my surroundings, when I believe that God exists and that this world is God's world; and if I will with all the strength of my soul to hold fast to the absolute ought, and that itself is an absolute willing, then I must believe absolutely that God is; faith is the absolute and highest requirement" (Hua XLII: 308, as quoted by Melle 2007: 15). The subject has no knowledge of the existence of God, but it can posit God on the basis of a motivation of the heart: "The world 'has to' be a lovely and good one, one that has a universal teleology" (Hua XLII: 254). Human action is free and responsible, but human action must be divinely guided; "all irrational contingencies, all sinful confusions, all irrational disturbances" (Hua XLII: 254) have to be the practical background to a universal teleology and everything therein must also have a teleological function in order that a "free, responsible human life in the world be possible" (Hua XLII: 254). For the sake of its self-preservation as a person, it must believe in God insofar as "I live, I have to be able to live, I can only live in hope, I can only truly live in vocation and in the hope that it presupposes za. I believe not out of arbitrariness, but out of the necessity to be me, and a member of mankind (...) Destiny and misery bring faith into being and with it the overcoming of destiny" (Hua XLII: 407). Much like Nietzsche, Husserl claims that this is the "absolute ought, which affirms life because of the misery, the reality and possibility of one's own and others' destinies" (Hua XLII: 408); an absolute ought that needs the support of loving faith.

\section{Conclusion: The Re-establishment of the Unity of Ontological Reality: The Open, Historical Essence of a Person and its Universalisation as a Transcendental Person}

At this point we are able to take up the problem of the split in the ontological reality caused by the break between the scientific and the phenomenological attitudes. The first step towards bridging this gap is the consideration of the open essence of a thing which is afterwards extended to the Ego. Husserl asks himself whether a thing is "an identical subject of identical properties" and whether its behaviour is "predelineated by its own essence" (Ideas II: 312). The ground-breaking question, which breaks with the Aristotelian tradition, reads: "But does each thing (...) have such an essence of its own in the first place? Or is the thing, as it were, always underway, (...) in principle only a relatively identical something, which does not have its essence in advance or graspable once and for all, but instead has an open essence, one that can always take on new properties according to the 
circumstances of givenness?" (Ideas II, 313). This question leads him to acknowledge that the Ego is not an empty pole but is the "bearer of its habitualities", i.e. it has "its individual history". Although a personal Ego has an absolute individuation, as stated above, it "allows itself to be determined by its 'over and against' in the surrounding world" and by its own "history" (Ideas II: 314f.) such that it acquires new properties. This means that the I as an ensouled nature acquires new habits in response to its cultural environment, habits which were not part of its original essence. The condition of the possibility for this capacity of transformation is the 'flexible' nature of our consciousness: "Consciousness has its own essence, one in flux and not determinable exactly" (Ideas II: 315). To restore the unity of both approaches we need to relate this essential openness of consciousness to the I as person. Husserl does precisely this when he claims "[a]bsolute individuation enters into the personal Ego" (Ideas II: 315). This means that the person is the only reality which has a personal, individual I, is bearer of habitualitites and therefore has a personality with an individual history. The essence of the personal I can therefore change and assume new properties, according to its own history, while being related to nature through its cultural and scientific achievements.

We have already seen that a person as moral person realises its ethical existence under the guidance of practical reason. This telos of an ethical life-form that rules the whole of an individual life according to the individual categorical imperative guided by love can be achieved in various manners, for example through scientific activity, through political or artistic life (Hua XXVII: 40). Science and the lifeworld are closely connected - if severed, then a crisis ensues (cf. Crisis). Life in its full sense is not merely a life devoted to practical interests but one that serves theoretical interests too. This is what "renders the human subject to its fullness as person" (Luft 2012: 37). Husserl terms this person as the "transcendental person who, entering into the universality of the concrete transcendental, appropriates for itself the wholly encompassing life" (Hua XXXIV: 200f., as quoted in Luft 2012: 37). It is precisely around this person insofar as it is transcendental that Husserl's moral-ethical reflections crystallise. Hence, if the transcendental Ego itself is construed from out of the context of the personal Ego and this personal Ego is nothing other than a moral person, then we may conclude that the transcendental person is the universal structure underlying any individual Ego with its individual life. We may also conclude that the unity of ontological reality, the unity of the lifeworld and science, is re-composed by an ethical demand that rules not only the life of individuals, but that of communities as well, as both share a universal character - that of being moral persons. 
Bibliography

Hart J., 1992, The Person and the Common Life: Studies in a Husserlian Social Ethics, Dordrecht: Kluwer Academic Publishers.

Hart J., 1995, Husserl and Fichte - with Special Regard to Husserl's Lectures on „Fichte's Ideal of Humanity", Husserl Studies, vol. 12, pp. 135-163.

Husserl E., 1959, Hua VIII, Erste Philosophie (1923/24). Zweiter Teil. Theorie der Phänomenologischen Reduktion, R. Boehm (ed.), The Hague: Martinus Nijhoff.

Husserl E., 1973, Hua XIV, Zur Phänomenologie der Intersubjektivität. Texte aus dem Nachlass. Zweiter Teil: 1921-1928, I. Kern (ed.), The Hague: Martinus Nijhoff.

Husserl E., 1973, Hua XV, Zur Phänomenologie der Intersubjektivität. Texte aus dem Nachlass. Dritter Teil: 1929-1935, I. Kern (ed.), The Hague: Martinus Nijhoff.

Husserl E., 1974, The Crisis of European Sciences and Transcendental Phenomenology, transl. D. Carr, Evanston: Northwestern University Press.

Husserl E., 1974, Hua XXVIII, Vorlesungen über Ethik und Wertlehre (1908-1914), U. Melle (ed.), Dordrecht: Kluwer Academic Publishers.

Husserl E., 1989, Hua XXVII, Aufsätze und Vorträge (1922-1937), T. Nenon, H.R. Sepp (eds.), Dordrecht-Boston-London: Kluwer Academic Publishers.

Husserl E., 1989, Ideas pertaining to a Pure Phenomenology and to a Phenomenological Philosophy, second Book, Studies in the Phenomenology of Constitution, transl. R. Rojcewicz, A. Schuwer, Dordrecht-Boston-London: Kluwer Academic Publishers.

Husserl E., 2002, Hua XXXV, Einleitung in die Philosophie. Vorlesungen 1922/23, B. Goosens (ed.), Dordrecht-Boston-London: Kluwer Academic Publishers.

Husserl E., 2004, Hua XXXVII, Einleitung in die Ethik. Vorlesungen Sommersemester 1920/1924, H. Peucker (ed.), Dordrecht-Boston-London: Kluwer Academic Publishers.

Husserl E., 2012, Hua Mat. IX, Einleitung in die Philosophie 1919/1920, H. Jacobs (ed.), Dordrecht-Heidelberg-New York-London: Springer.

Husserl E., 2014, Hua XLII, Grenzprobleme der Phänomenologie. Analysen des Unbewusstseins und der Instinkte. Metaphysik. Späte Ethik. Texte aus dem Nachlass (1908-1937), R. Sowa, T. Vongehr (eds.), Dordrecht-Heidelberg-New York-London: Springer.

Husserl E., unpublished manuscript, Ms. A VI 21, p. 21 a and b, quoted in Marbach 1974: 315.

Husserl E., unpublished manuscript, Ms. E III, 2, p. 5a, quoted in Marbach 1974: 304.

Husserl E., unpublished manuscript, Ms. B I 21, p. 55, quoted in Melle 2007: 12.

Luft S., 2012, The Subject as Moral Person. On Husserl's late Reflections concerning the Concept of Personhood [in]: Investigating Subjectivity. Classical and New Perspectives, G.-J. van Der Heiden, K. Novotny, I. Römer, L. Tengelyi (eds.), Leiden-Boston: Brill, pp. 25-43.

Marbach E., 1974, Das Problem des Ich bei Husserl, The Hague: Martinus Nijhoff.

Melle U., 2008, Einleitung to Husserl E., 1988, Hua XXVIII, pp. xiii-xlix.

Melle U., 1991, The Development of Husserl's Ethics, Études Phénoménologiques, no. 13-14, pp. 115-135.

Melle U., 2002, From Reason to Love [in:] Phenomenological Approaches to Moral Philosophy: A Handbook, J. Drummond, L. Embree (eds.), Dordrecht: Kluwer Academic Publishers, pp. 229-248.

Melle U., 2007, Husserl's Personalist Ethics, Husserl Studies, vol. 23, pp. 1-15. 
Peucker H., 2008, From Logic to the Person: An Introduction to Edmund Husserl's Ethics, The Review of Metaphysics, vol. 62, pp. 307-325.

Peucker H., 2010, Aristotelische Elemente in der Ethik Edmund Husserls, Philosophisches Jahrbuch, vol. 117, pp. 54-68.

Peucker H., 2011, Die ethischen Grundlagen von Husserls Philosophie, Journal Phänomenologie, vol. 36, pp. 10-20.

Ricour P., 1992, Oneself as Another, transl. K. Blamey, Chicago-London: The University of Chicago Press.

Sokolowski R., 2017, Moral Action. A Phenomenological Study, Washington, D.C.: The Catholic University of America Press.

Sowa R., Vongehr T., 2012, Einleitung to Husserl, Edmund, 2014, Hua XLII, pp. xix-cxv. 